\title{
Evaluation of benthic macroinvertebrate assemblage for disturbance zonation in urban rivers using multivariate analysis: Implications for river management
}

\author{
Ram Devi Tachamo Shah* and Deep Narayan Shah \\ Hindu Kush Himalayan Benthological Society, Kathmandu, Nepal. \\ ${ }^{*}$ Corresponding author. e-mail: ramdevishah@yahoo.com
}

\begin{abstract}
River pollution has tremendously increased in the major cities of South Asia, where the rivers have become a repository for domestic, agricultural, municipal and industrial wastes. This study presents the evaluation of benthic macroinvertebrate assemblage as a means of assessing ecological status, determining different disturbance zones and identifying environmental variables and stressors that deteriorate the river ecosystem. In total, 20 sites in $36-\mathrm{km}$ stretch of the main stem of the Bagmati River and 7 sites on its tributaries were selected for sampling in the post-monsoon and pre-monsoon seasons during the time period 2008-2010. The Ganga River System Biotic Score (GRSbios) index was applied to determine the ecological status. The ecological status of the different Bagmati River stretches ranged from reference (Class 1) to extremely polluted (Class 5). We identified three types of disturbance zones along the river, ranging from minimally polluted to extremely polluted. A river corridor survey was conducted to identify any river stressing factors, revealing a sharp deterioration of the river from upstream to downstream with increasing concentrations of chloride and ortho-phosphate phosphorus. Effluents and Activities and Facilities were found to be the major stressing factors to the river ecosystem. The information gained should help water managers find the most time-efficient and cost-effective measures to address river degradation.
\end{abstract}

\section{Introduction}

The river pollution in South Asia has increased with the urbanization of its countries as elsewhere in the world due to the direct discharge of untreated sewage, industrial wastes and municipal wastes. Urban river pollution used to be a major problem for today's developed central European countries (Stubauer et al. 2010), Australia and America (Campbell 1978) in the first years of the twentieth century. With growing concern in the community and government about the degradation of surface water, various assessment programmes have been launched throughout these countries. As a result, river restoration practices have been implemented and today the organic river pollution is gradually decreasing. For example, the European Water Framework Directive (WFD) has provided clear mandates for achieving a qualitatively and quantitatively good ecological status by improving the chemical status of all the surface water in Europe (European Commission 2000). Such a framework guiding the status of surface water is largely missing in South Asia.

Anthropogenic influence as well as natural processes degrade surface water quality and impair

Keywords. Benthic macroinvertebrates; cluster analysis; disturbance zonation; restoration; river pollution. 
the use of water for drinking, industrial, agricultural, recreational or other purposes. The influence of human activities on the surface waters of South Asia has increased dramatically during the past decades (Karn and Harada 2001; Kannel et al. 2007a). Nepal is no exception, making water and environmental degradation an ongoing serious concern in the major cities of Nepal, for example, in Kathmandu (Kannel et al. 2007a; Shrestha et al. 2008a; NTNC 2009), in Hetauda and in Nepaljung (Ghimire 1985). High water turbidity, low dissolved oxygen and an increase in nitrogen and phosphorus compounds (Kannel et al. 2007a) have not only produced odour and aesthetic nuisances in the urban areas of Nepal but have also led to a decrease in aquatic life in urban rivers (Shah et al. 2008). A study of the Bagmati River covering the time period 1999-2003 revealed that the biochemical oxygen demand $\left(\mathrm{BOD}_{5}\right)$, total phosphorous (TP), total inorganic nitrogen (TIN) and total suspended solids (TSS) were above 39.1, 10.1, 0.84 and $199 \mathrm{mg} / \mathrm{l}$, respectively, in urban areas which were two to five times higher than the rural areas (Kannel et al. 2007a). Shah et al. (2008) demonstrated a sharp increase in the community loss index in the downstream river section at Chovar (14.5) compared to the upstream river section at Sundarijal (0.94).

Rivers that transport domestic and industrial wastewater and nonpoint source pollutants from their catchments are thus among the water bodies most vulnerable to pollution (Zhang et al. 2009). Identifying and quantifying any contaminant inputs as well as understanding their sources are crucial for planning, mitigation and restoration processes (Williams 1998). As awareness increases regarding freshwater systems' benefit to the public and to aquatic life, the assessment and classification of water qualities to determine effective management options are becoming a concern (Kannel et al. 2007b).

The surface water assessment and monitoring in Asian countries are largely based on chemical data analysis. Some Asian countries using such water assessment methods include Nepal (Ha and Pokhrel 2001; Kannel et al. 2007a), China (Zhou et al. 2007; Zhang et al. 2009), India (Raj and Azeez 2009; Bhardwaj et al. 2010) and Malaysia (Fulazzaky et al. 2010). However, as studies have shown in continental Europe, Australia, the United States and Great Britain, biological data are a worthwhile addition to chemical data analysis for detecting river degradation and are widely accepted all over the world (Barbour 2008; Stubauer et al. 2010). Yet biological assessment is limited in countries where environmental protection is in its infancy (Barbour 2008). The importance of biological assessment is also reflected from the results of Commonwealth Environment Protection Agency (CEPA 1992) which showed the streams in cleared areas were in the worst biological condition, a result not indicated by the physical factors. Biological indicators are commonly used to evaluate and characterize the ecological changes in streams (Bonada et al. 2006). Among the various biological indicators (such as algae, periphyton, macrophytes, benthic invertebrates and fish), benthic macroinvertebrates are the most commonly used biotic assemblage across the world (Rosenberg and Resh 1993; Resh 2008). As a result of the benthic macroinvertebrate community's continuous exposure to pollution, the community's species composition changes in response to the magnitude, duration and frequency of the pollutants and human disturbance (Bonada et al. 2006; Barbour 2008). Benthic macroinvertebrates are abundant in many streams, long-lived compared to algae, possess varying tolerances to perturbations in streams, and are cost-effective to sample, making them an ideal biological indicator (Rosenberg and Resh 1993). Based on the tolerance of the benthic macroinvertebrate taxa to pollution gradients, tolerance scores (e.g. Ganga River System biotic score-GRSbios) are assigned to individual taxa, providing a biotic index for assessing the ecological river quality. In general, Ephemeroptera, Plecoptera and Trichoptera have higher taxa tolerance scores due to their specific habitat requirements and sensitivity to disturbance.

The ecological river quality largely depends on stressor types (e.g. waste dumping, effluents, hydro-morphological disturbances, etc.) which differ along the urban river, making river restoration and management very challenging. The stressors which are critical for one section may not be critical for other section of a river (NTNC 2009). Thus, different levels of mitigative and restoration processes need to be considered depending upon the respective human disturbance gradients. The classification of disturbance gradients into different zones using multivariate statistical methods allows river managers to develop and implement effective management programmes which optimize cost and time without reducing the outcome quality significantly.

In the present study, different statistical techniques are applied to a data matrix, obtained during a 2-year (2008-2010) monitoring programme, to extract information on ecological status, disturbance zones, influencing environmental variables and stressing factors; this information provides the basis for developing urban river restoration and management strategies. This study aims to provide policy makers, researchers and river managers of South Asian countries with a scientific understanding of how benthic macroinvertebrate 
assemblage may be used for river quality assessment and classification to facilitate effective river management.

\section{Materials and methods}

\subsection{Study area}

The study area covers $36-\mathrm{km}$ stretch of the Bagmati River in the Kathmandu Valley, Nepal (figure 1). The valley lies between the latitudes $27^{\circ} 32^{\prime} 13^{\prime \prime}$ and $27^{\circ} 49^{\prime} 10^{\prime \prime} \mathrm{N}$ and the longitudes $85^{\circ} 11^{\prime} 31^{\prime \prime}$ and $85^{\circ} 31^{\prime} 38^{\prime \prime} \mathrm{E}$. It is surrounded by the hills of the Mahabharat Range, forming a bowlshaped valley floor. The Bagmati River originates in the village of Bagdwar, located in the Shivapur ridge (Shivapuri Nagarjun National Park), and leaves the valley through the Chovar Gorge. The average current velocity has been recorded as $1 \mathrm{~m} / \mathrm{s}$ in the river stretches inside the national park which reduced to $0.3 \mathrm{~m} / \mathrm{s}$ in downstream of the river (Pradhan 2005). Six major tributaries drain into the river: the Nagmati, Manahara, Dhobi, Bishnumati, Nakhu and Balkhu. Except Nagmati, all the rivers pass through major polluting cities of Bhaktapur, Lalitpur and Kathmandu. All the rivers are fed by spring and monsoon rainfall. The average annual rainfall is $1900 \mathrm{~mm}$, of which about $80 \%$ occurs during monsoon season (June-September). The river basin covers an area of about $650 \mathrm{~km}^{2}$ with an altitude varying from 1220 to $2800 \mathrm{~m}$ above mean sea level. The basin has a warm temperate climate where summer temperatures range from $19^{\circ}$ to $27^{\circ} \mathrm{C}$ and winter temperatures range from $2^{\circ}$ to $20^{\circ} \mathrm{C}$ (NTNC 2009). The river is an important source of water for drinking, industrial applications, irrigation and recreation for about 1.6 million people (CBS 2002) in the valley.

\subsection{Sampling sites and approach}

In total, 20 sites on the Bagmati River and one site on each of its major tributaries (table 1) before inlet into the Bagmati (figure 1) were investigated

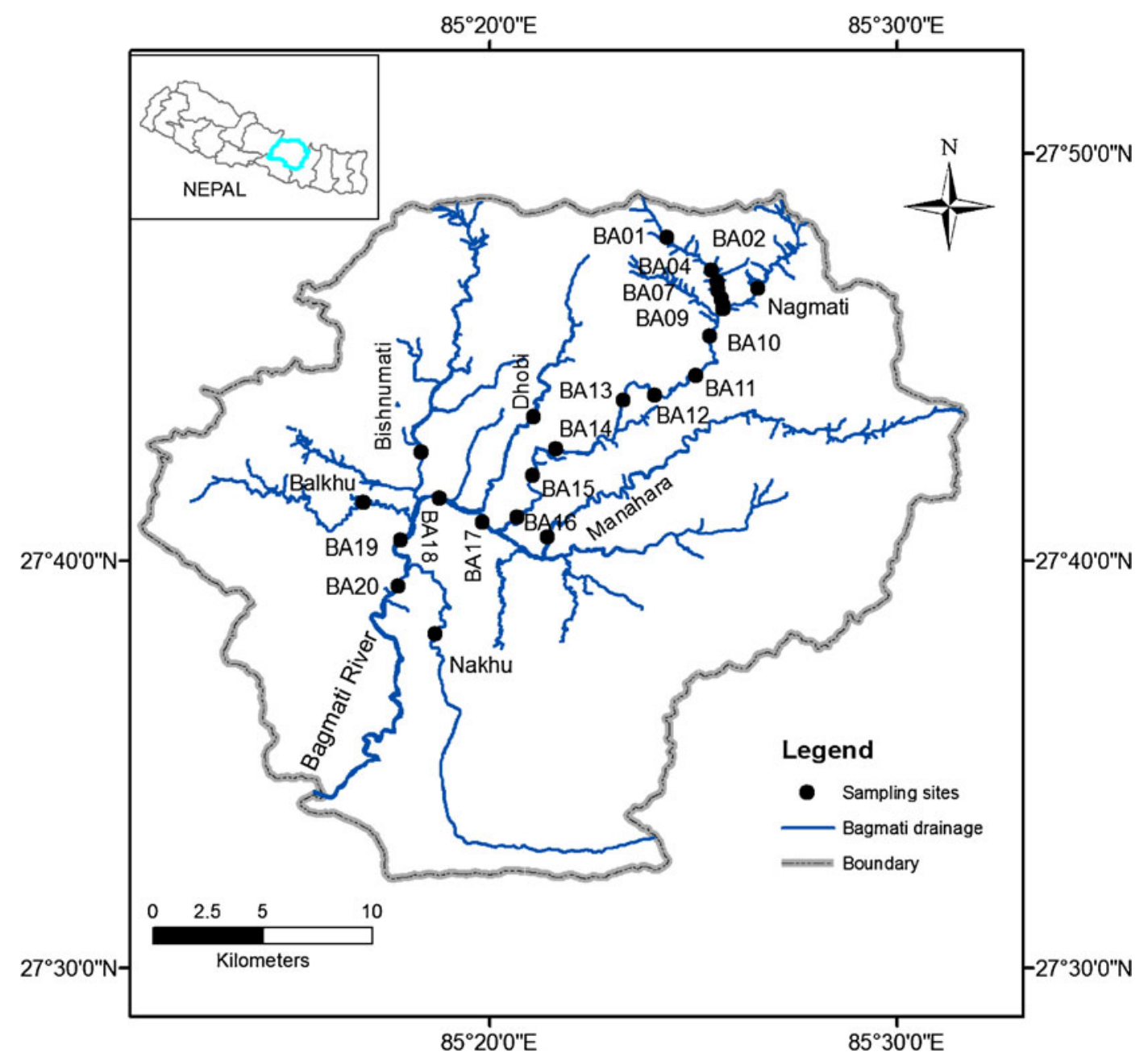

Figure 1. Map of Bagmati River basin showing sampling sites in the Bagmati River (BA01-BA20) and its tributaries: Nagmati, Dhobi, Manahara, Bishnumati, Balkhu and Nakhu Rivers. 
Table 1. Geographic location of sampling sites on the Bagmati River and on its tributaries. (Abbreviations: BER - Bed Rock, BAU - Boulder, STO - Stone, PEB - Pebble, GRA - Gravel, SAN - Sand, CLY - Clay and SLG - Sludge.)

\begin{tabular}{|c|c|c|c|}
\hline Site code & Latitude & Longitude & Substrate types \\
\hline BA01 & 27.79868 & 85.40448 & BER, BAU, STO, PEB, GRA, SAN, CLY \\
\hline BA02 & 27.78495 & 85.42343 & BAU, STO, PEB, GRA, SAN \\
\hline BA03 & 27.78143 & 85.42378 & BER, BAU, STO, PEB, GRA, SAN \\
\hline BA04 & 27.77935 & 85.42447 & BER, BAU, STO, PEB, GRA, SAN, CLY \\
\hline BA05 & 27.77518 & 85.42492 & BER, BAU, STO, PEB, GRA, SAN \\
\hline BA06 & 27.77168 & 85.42642 & BER, BAU, STO, PEB, SAN \\
\hline BA07 & 27.77032 & 85.42663 & BER, BAU, STO, PEB, GRA, SAN \\
\hline BA08 & 27.75810 & 85.42093 & BER, BAU, STO, PEB, GRA, SAN, CLY \\
\hline BA09 & 27.74437 & 85.41717 & STO, PEB, GRA, SAN \\
\hline BA10 & 27.73587 & 85.39663 & PEB, GRA, SAN, CLY \\
\hline BA11 & 27.73947 & 85.38887 & BAU, STO, PEB, GRA, SAN, CLY \\
\hline BA12 & 27.71060 & 85.35457 & STO, PEB, GRA, SAN, CLY, SLG \\
\hline BA13 & 27.70633 & 85.34905 & PEB, GRA, SAN, CLY, SLG \\
\hline BA14 & 27.68465 & 85.34328 & STO, SLG \\
\hline BA15 & 27.68033 & 85.33027 & STO, SAN, SLG \\
\hline BA16 & 27.69163 & 85.31183 & SAN, CLY, SLG \\
\hline BA17 & 27.69058 & 85.30185 & STO, PEB, SAN, SLG \\
\hline BA18 & 27.68562 & 85.30027 & STO, PEB, GRA, SAN, SLG \\
\hline BA19 & 27.68238 & 85.29908 & STO, CLY, SLG \\
\hline BA20 & 27.65758 & 85.29368 & BER, BAU, STO, SLG \\
\hline NAG & 27.77003 & 85.42785 & BER, BAU, STO, PEB, GRA, SAN, CLY \\
\hline MAN & 27.66818 & 85.35053 & STO, SAN, SLG \\
\hline BIS & 27.69215 & 85.30138 & STO, GRA, SAN, CLY, SLG \\
\hline $\mathrm{DHO}$ & 27.72395 & 85.34652 & STO, SAN, SLG \\
\hline NAK & 27.66238 & 85.30543 & BAU, STO, SLG \\
\hline BAL & 27.68532 & 85.29780 & BAU, STO, GRA, CLY, SLG \\
\hline
\end{tabular}

for biological and environmental variables. The decision on number of sites and selection of locations was done carefully based on type of stressors and its intensity to the river stretches to meet the objectives of the study as the choice of sampling impacts the conclusion drawn about impairment (Downes et al. 2002). The first sampling site (BA01) is located less than $2 \mathrm{~km}$ from the river origin. The sites BA02-BA07 are situated in rural (naturally forested) areas with minimal human disturbances, sites BA08-BA11 are in semi-urban areas, and the remaining sites are in urban areas. The sites were sampled twice in each season, post-monsoon (November 2008 and 2009) and pre-monsoon (April 2009 and 2010), resulting in 80 samples for the Bagmati River. Monsoon season was not considered for sampling because frequent flood events reduce the differentiation between inter-sites (sensu Leung et al. 2012). Also, the possibility of drifting benthic macroinvertebrates by flood events (e.g. Robinson et al. 2004) could either under or overestimate the ecological status of the river segment. The benthic samples were collected using a multihabitat sampling approach (Moog 2007) reflecting the proportion of the microhabitat types present with cover greater than or equal to $5 \%$ at each stream reach. At each site, 20 sampling units were taken within a $100-\mathrm{m}$ river stretch using a net with a surface area of $0.25 \times 0.25 \mathrm{~m}$ and a mesh size of $500 \mu \mathrm{m}$, effectively sampling $1.25 \mathrm{~m}^{2}$ of the stream bottom. The composite sample collected in this way was then placed in a labelled plastic container and fixed in situ using $4 \%$ formaldehyde. In the laboratory, the samples were washed, sieved, sorted and identified to family level based on available keys (Dudgeon 1999; Nesemann et al. 2007, 2011) with the help of a stereo microscope.

The dissolved oxygen, temperature, $\mathrm{pH}$, conductivity, turbidity, free carbon dioxide and chloride were measured using a standard field kit in field, while the nitrate nitrogen, ortho-phosphate phosphorus, biological oxygen demand $\left(\mathrm{BOD}_{5}\right)$ and ammonia nitrogen were carried out in the laboratory (based on APHA 1995).

\subsection{River corridor survey}

For each of the selected sampling sites, the 500-m section of the river directly upstream from the sampling site was sketched. The features of the river 
such as bank condition and structure, bed materials, riparian vegetation, flood plain land use, flow conditions (pool, riffles, runs, rapids) and stressors like transverse structures (bridge, weirs, dams, sediment bars), ritual activities (holy bath, waste from temple, cremation ashes), sewerage discharge, sand mining, water abstraction, solid waste disposal, washing and bathing, bank modification and pavement were recorded at each site. This corridor survey reflects the present riverine environment including the current stressors to the riverine ecosystem and their impacts (Shrestha et al. 2008a).

\subsection{Data analysis}

The ecological status of the Bagmati River and its tributaries were determined by using the GRSbios index (Nesemann et al. 2007; Shah and Shah 2012). The index is calculated for each site by dividing sum of taxa score by number of scored taxa that results Ganga River System Biotic Score/Average Score per Taxon (GRSbios/ASPT). This value reflects the overall river ecosystem health by accounting for the cumulative effects from organic pollution, land use change and hydromorphological degradation.

The biological abundance data were transformed to $\log (\mathrm{X}+1)$ for multivariate analysis and were not transformed further. Prior to multivariate analysis, an outlier test was conducted using the software PC-ORD version 5 (McCune and Mefford 2006) with a maximum acceptable variation of two standard deviations and the Sørensen (Bray-Curtis) as a distance measure.

Cluster analysis (CA) and non-metric multidimensional scaling (NMDS) were conducted using the software PC-ORD to group sites based on the benthic macroinvertebrates' assemblage and abundance for each season. Significant number of clusters were used to categorize disturbance zones along the Bagmati River. The usefulness of CA for grouping sampling sites based on macroinvertebrate composition and abundance has been proven in previous studies (Marchant et al. 2000).

Diversity indices (Shannon diversity, Evenness and Simpson diversity) were calculated in PC-ORD version 5 (McCune and Mefford 2006). Taxa richness, total abundance, percentage of Ephemeroptera, Plecoptera and Trichoptera (EPT) abundance and percentage of Worm and Leeches (WL) abundance were calculated separately. The calculation methods are presented in table 2. Analyses were carried out based on pre-monsoon season data to capture the most polluted scenario in the river.

The identification of environmental variables influencing the benthic assemblage for each season was analyzed by using Canonical Correspondence Analysis (CCA) in the software CANOCO version 4.5 (Ter Braak and Smilauer 2002). CCA, a direct gradient analysis, uses regression procedures to relate species with environmental data and assumes that species have unimodal responses to environmental variables. The forward selection procedure, which uses a partial Monte Carlo permutation test, was performed to assess the usefulness of each potential predictor variable for extending the subset of explanatory variables used in the ordination model. All the significant variables $(p<0.05$ in the Monte Carlo tests) were retained in the analysis and were incorporated in the CCA biplot.

The documented stressors were categorized into four broader categories (modified from Shrestha et al. 2009): Effluents, Solid waste, Activities and Facilities, and Hydro-morphological disturbances. The categorizations are based on types of waste

Table 2. Calculation methods of metrics.

\begin{tabular}{|c|c|}
\hline Metrics & Calculation \\
\hline Taxa richness & Total number of present taxa in a site \\
\hline Total abundance & Total number of individuals in a site \\
\hline Percentage of EPT abundance & $\begin{array}{l}\text { (Sum of Ephemeroptera, Plecoptera and Trichoptera } \\
\text { individuals in a site/Total abundance in a site) } * 100\end{array}$ \\
\hline Percentage of Worms and Leeches abundance & Percentage of worms and leeches individuals in a site \\
\hline \multicolumn{2}{|l|}{ Diversity indices } \\
\hline Shannon's diversity index $(\mathrm{H})$ & $\begin{array}{l}-\Sigma p_{i} * \ln p_{i} \\
p_{i}=\text { relative abundance of } i \text { th taxa }\end{array}$ \\
\hline Evenness (e) & $\begin{array}{l}H / \ln S \\
\text { with } H=\text { Shannon's diversity index, } S=\text { Taxa richness }\end{array}$ \\
\hline Simpson's diversity index (D) & $\begin{array}{l}1-\Sigma\left(p_{i} * p_{i}\right) \\
p_{i}=\text { relative abundance of } i \text { th taxa }\end{array}$ \\
\hline
\end{tabular}


generated and disturbances to the riverine ecosystems. All kinds of liquid waste discharged into the river are included in Effluents category. Municipal and other kinds of solid waste deposited along the river banks are categorized as Solid waste. Activities and Facilities include waste and disturbances generated during human activities in the riverine environment while Hydro-morphological disturbances category includes the processes and activities that change the habitat structures and flow condition of the river. The relative importance of the stressors was computed in terms of percentage sharing for the disturbance zones of the premonsoon seasons. A nonparametric Kruskal-Wallis test was performed to determine any variation in the benthic composition among the disturbance zones. All the statistical analyses were conducted using SPSS software (version 17.0 for Windows; SPSS Inc, Chicago, IL).

\section{Results}

\subsection{Ecological status}

The ecological status of the different stretches of the Bagmati River ranged from Class 1 to Class 5 , that is, reference, slightly polluted, moderately polluted, heavily polluted and extremely

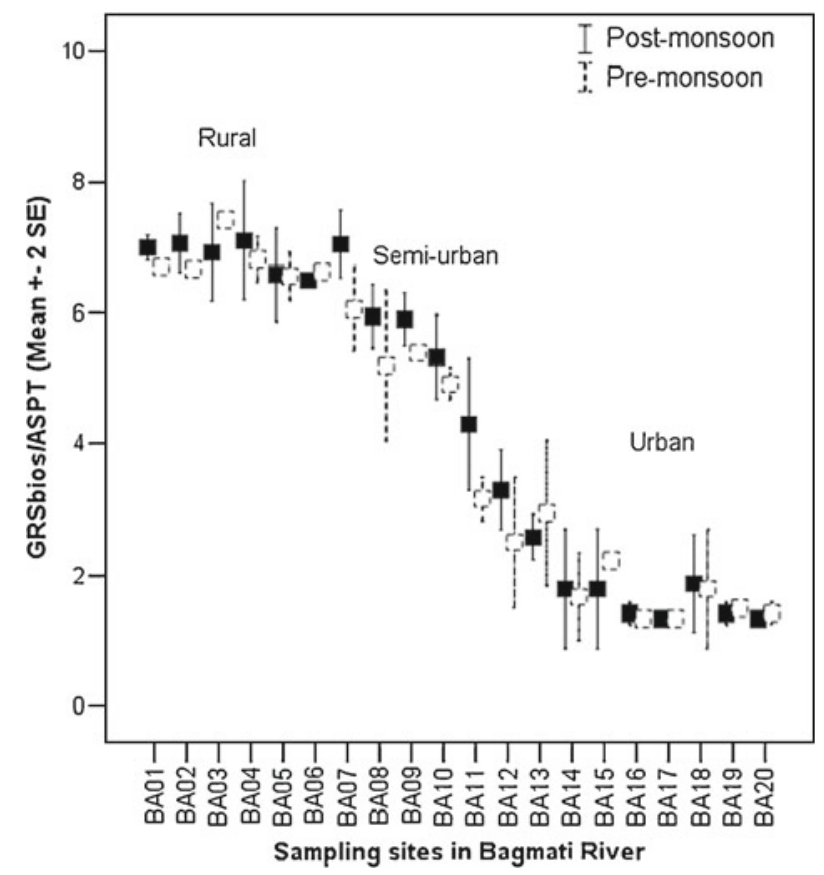

Figure 2. The GRSbios/ASPT value for post-monsoon and pre-monsoon seasons at each sampling site $(n=2)$ in Bagmati River. (Abbreviations: SE: standard error, sites BA01-BA07 lie in rural area, BA08-BA10 in semi-urban and BA11-BA20 in urban area.) polluted (figure 2). Reference and slight pollution were restricted to rural areas (within the national park), moderate pollution was recorded in semiurban areas, and heavy to extreme pollution was recorded in urbanized areas. The GRSbios/ ASPT value ranged from 6.19 to 7.57 in rural areas (BA01-BA07), 4.62 to 6.19 in semi-urban areas (BA08-BA10) and 1.33 to 4.80 in urban areas (BA11-BA20) for both seasons. One tributary, the Nagmati River, was in reference status (GRSbios/ ASPT 7.5), and all the other tributaries were extremely polluted (GRSbios/ASPT <2.0). The total taxa richness decreased from up- to downstream section while EPT taxa richness decreased from BA01 to BA12 and were not recorded from BA13 to BA20 (figure 3).

The dissolved oxygen decreased downstream with increasing pollution level (BA01-BA20). In contrast, the nitrate nitrogen, ortho-phosphate phosphorus, chloride and $\mathrm{BOD}_{5}$ sharply increased in the downstream river sections (table 3 ). The dissolved oxygen showed higher levels in the upstream section (max. $8.5 \mathrm{mg} / \mathrm{l}$, post-monsoon season and min $6.3 \mathrm{mg} / \mathrm{l}$, pre-monsoon season) and the lowest levels in the downstream urban section (max. 3.8 and $\min .0 .5 \mathrm{mg} / \mathrm{l}$ ). The ortho-phosphate phosphorus concentration increased with increasing pollution level $(<0.05$ to $0.17 \mathrm{mg} / \mathrm{l}$ from sites BA01 to BA07, $0.21-0.37 \mathrm{mg} / \mathrm{l}$ from sites BA08 to BA10 and $0.42-6.36 \mathrm{mg} / \mathrm{l}$ from sites BA11 to BA20). The environmental variables of the tributaries are presented in table 4 .

\subsection{Disturbance zonation}

The cluster analysis (CA) classified the sites into three statistically significant clusters for

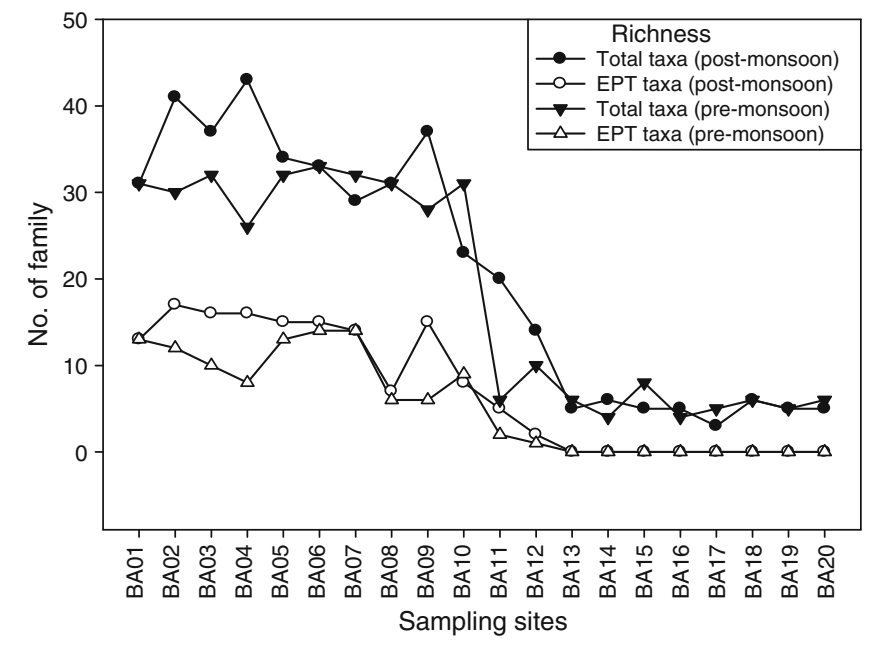

Figure 3. Total taxa richness and EPT taxa richness for post-monsoon and pre-monsoon seasons at each site. 
Table 3. Mean value and standard error of the mean of environmental variables along Bagmati River. (Abbreviations: Temp $=$ temperature $(\mathrm{C})$, Cond. $=$ conductivity $(\mu \mathrm{S} / \mathrm{cm})$, Turb. = turbidity $(\mathrm{NTU}), \mathrm{DO}=$ dissolved oxygen $(\mathrm{mg} / \mathrm{l}), \mathrm{Free} C \mathrm{O}_{2}$ $(\mathrm{mg} / \mathrm{l}), \mathrm{Cl}=$ chloride $(\mathrm{mg} / \mathrm{l}), \mathrm{BOD} \mathrm{D}_{5}=$ biological oxygen demand $(\mathrm{mg} / \mathrm{l}), \mathrm{NO}_{3}-\mathrm{N}=$ nitrate nitrogen $(\mathrm{mg} / \mathrm{l}), \mathrm{PO}_{4}-\mathrm{P}=$ ortho-phosphate phosphorus ( $\mathrm{mg} / \mathrm{l}), \mathrm{NH}_{4}-\mathrm{N}=$ ammonium nitrogen $(\mathrm{mg} / \mathrm{l})$.)

\begin{tabular}{|c|c|c|c|c|c|c|c|c|c|c|c|c|}
\hline & & Temp & $\mathrm{pH}$ & Cond. & Turb. & $\mathrm{DO}$ & $\begin{array}{l}\text { Free } \\
\mathrm{CO}_{2}\end{array}$ & $\mathrm{Cl}$ & $\mathrm{BOD}_{5}$ & $\mathrm{NO}_{3}-\mathrm{N}$ & $\mathrm{PO}_{4}-\mathrm{P}$ & $\mathrm{NH}_{4}-\mathrm{N}$ \\
\hline \multirow[t]{2}{*}{ BA01 } & mean & 15.85 & 7.43 & 25.00 & 1.63 & 7.09 & 5.50 & 2.93 & 1.38 & 0.05 & 0.05 & 0.05 \\
\hline & SEM & 3.29 & 0.02 & 0.71 & 0.62 & 0.43 & 2.33 & 0.90 & 0.19 & 0.00 & 0.00 & 0.00 \\
\hline \multirow[t]{2}{*}{ BA02 } & mean & 15.95 & 7.63 & 26.38 & 2.15 & 7.40 & 8.42 & 4.99 & 1.58 & 0.05 & 0.05 & 0.05 \\
\hline & SEM & 3.75 & 0.02 & 0.97 & 0.95 & 0.79 & 4.39 & 1.95 & 0.23 & 0.00 & 0.00 & 0.00 \\
\hline \multirow[t]{2}{*}{ BA03 } & mean & 14.97 & 7.35 & 27.08 & 1.72 & 6.71 & 7.52 & 7.25 & 1.55 & 0.07 & 0.05 & 0.05 \\
\hline & SEM & 2.85 & 0.11 & 1.00 & 0.43 & 0.31 & 3.24 & 2.36 & 0.11 & 0.00 & 0.00 & 0.00 \\
\hline \multirow{2}{*}{ BA04 } & mean & 15.03 & 7.50 & 27.75 & 4.00 & 7.69 & 5.94 & 8.62 & 1.70 & 0.12 & 0.16 & 0.16 \\
\hline & SEM & 3.16 & 0.11 & 1.59 & 1.06 & 0.29 & 1.87 & 2.81 & 0.32 & 0.02 & 0.07 & 0.05 \\
\hline \multirow[t]{2}{*}{ BA05 } & mean & 14.63 & 7.60 & 36.25 & 6.10 & 7.59 & 1.93 & 8.85 & 1.90 & 0.12 & 0.17 & 0.27 \\
\hline & SEM & 2.74 & 0.04 & 1.94 & 0.07 & 0.36 & 0.19 & 2.28 & 0.32 & 0.02 & 0.07 & 0.06 \\
\hline \multirow[t]{2}{*}{ BA06 } & mean & 15.00 & 7.73 & 27.75 & 4.75 & 7.69 & 5.50 & 8.75 & 1.98 & 0.24 & 0.13 & 0.30 \\
\hline & SEM & 2.83 & 0.05 & 4.07 & 0.88 & 0.29 & 1.56 & 2.72 & 0.37 & 0.05 & 0.04 & 0.07 \\
\hline \multirow[t]{2}{*}{ BA07 } & mean & 14.38 & 7.60 & 28.50 & 4.33 & 8.00 & 4.95 & 11.33 & 2.38 & 0.29 & 0.13 & 0.35 \\
\hline & SEM & 2.39 & 0.07 & 3.18 & 1.36 & 0.21 & 1.17 & 2.53 & 0.34 & 0.04 & 0.04 & 0.11 \\
\hline \multirow[t]{2}{*}{ BA08 } & mean & 15.88 & 7.68 & 61.75 & 5.50 & 7.49 & 8.25 & 12.95 & 2.60 & 0.34 & 0.21 & 0.40 \\
\hline & SEM & 3.09 & 0.02 & 5.13 & 1.06 & 0.57 & 1.17 & 3.36 & 0.60 & 0.05 & 0.10 & 0.11 \\
\hline \multirow[t]{2}{*}{ BA09 } & mean & 20.13 & 7.73 & 65.40 & 7.00 & 6.09 & 2.18 & 13.04 & 3.80 & 0.44 & 0.27 & 0.48 \\
\hline & SEM & 4.51 & 0.05 & 7.85 & 1.41 & 0.03 & 0.02 & 2.94 & 0.46 & 0.09 & 0.13 & 0.05 \\
\hline \multirow[t]{2}{*}{ BA10 } & mean & 20.43 & 7.80 & 105.00 & 29.00 & 5.97 & 2.78 & 13.66 & 4.38 & 0.52 & 0.37 & 0.66 \\
\hline & SEM & 4.65 & 0.04 & 5.30 & 12.73 & 0.97 & 0.34 & 2.86 & 0.41 & 0.06 & 0.07 & 0.10 \\
\hline \multirow[t]{2}{*}{ BA11 } & mean & 19.50 & 7.63 & 293.75 & 35.48 & 3.09 & 3.10 & 24.89 & 15.15 & 0.60 & 0.42 & 0.98 \\
\hline & SEM & 3.54 & 0.02 & 52.15 & 19.46 & 0.94 & 0.46 & 7.98 & 0.42 & 0.09 & 0.05 & 0.44 \\
\hline \multirow[t]{2}{*}{ BA12 } & mean & 20.18 & 7.43 & 366.00 & 16.45 & 3.23 & 3.60 & 29.17 & 19.70 & 0.79 & 0.57 & 6.32 \\
\hline & SEM & 3.94 & 0.02 & 6.72 & 4.00 & 0.43 & 0.11 & 7.16 & 0.95 & 0.01 & 0.14 & 2.99 \\
\hline \multirow[t]{2}{*}{ BA13 } & mean & 19.75 & 7.38 & 910.75 & 88.05 & 1.28 & 13.03 & 48.29 & 69.00 & 1.38 & 4.53 & 31.80 \\
\hline & SEM & 2.30 & 0.02 & 39.77 & 21.53 & 0.16 & 6.70 & 9.46 & 20.15 & 0.09 & 0.55 & 11.46 \\
\hline \multirow[t]{2}{*}{ BA14 } & mean & 20.88 & 7.12 & 614.25 & 82.75 & 1.84 & 8.43 & 51.60 & 86.75 & 2.45 & 5.40 & 25.15 \\
\hline & SEM & 2.92 & 0.02 & 181.55 & 10.08 & 0.12 & 3.48 & 13.86 & 14.67 & 0.12 & 1.13 & 6.22 \\
\hline \multirow[t]{2}{*}{ BA15 } & mean & 21.28 & 7.28 & 681.88 & 78.25 & 1.20 & 15.60 & 70.25 & 148.50 & 2.54 & 4.88 & 34.26 \\
\hline & SEM & 2.85 & 0.09 & 183.76 & 5.13 & 0.25 & 8.41 & 12.20 & 32.88 & 0.18 & 0.30 & 8.35 \\
\hline \multirow[t]{2}{*}{ BA16 } & mean & 21.50 & 7.25 & 686.75 & 91.25 & 1.05 & 15.18 & 75.50 & 149.25 & 3.34 & 6.17 & 29.90 \\
\hline & SEM & 2.83 & 0.11 & 203.82 & 14.67 & 0.32 & 8.01 & 9.90 & 24.22 & 0.06 & 0.08 & 6.65 \\
\hline \multirow[t]{2}{*}{ BA17 } & mean & 21.78 & 7.38 & 1021.50 & 110.50 & 0.92 & 16.00 & 92.25 & 180.75 & 3.43 & 6.36 & 42.34 \\
\hline & SEM & 3.02 & 0.05 & 269.05 & 0.35 & 0.20 & 8.49 & 11.84 & 24.22 & 0.01 & 0.92 & 8.02 \\
\hline \multirow[t]{2}{*}{ BA18 } & mean & 22.06 & 7.33 & 929.00 & 58.50 & 0.68 & 16.63 & 90.25 & 127.75 & 4.23 & 5.66 & 30.03 \\
\hline & SEM & 1.10 & 0.05 & 200.82 & 8.84 & 0.12 & 9.10 & 9.02 & 20.68 & 0.10 & 0.33 & 8.47 \\
\hline \multirow[t]{2}{*}{ BA19 } & mean & 21.75 & 7.35 & 988.50 & 102.50 & 1.00 & 15.90 & 94.75 & 109.50 & 4.52 & 5.34 & 51.25 \\
\hline & SEM & 1.59 & 0.04 & 218.14 & 10.25 & 0.28 & 8.56 & 12.20 & 1.77 & 0.04 & 0.57 & 1.94 \\
\hline \multirow[t]{2}{*}{ BA20 } & mean & 24.20 & 7.35 & 899.73 & 75.43 & 1.48 & 22.28 & 103.15 & 155.25 & 4.58 & 5.44 & 43.68 \\
\hline & SEM & 1.20 & 0.11 & 90.32 & 2.42 & 0.44 & 4.40 & 5.90 & 33.41 & 0.08 & 0.63 & 1.89 \\
\hline
\end{tabular}

the post-monsoon (figure $4 \mathrm{a}$ ) and pre-monsoon (figure 4b) seasons: 'Zone A', 'Zone B' and 'Zone C' (figure 4c). Sites from BA01 to BA09 for postmonsoon season and BA01 to BA07 for premonsoon season were grouped under Zone A. Sites from BA10 to BA12 in post-monsoon season and BA08 to BA10 in pre-monsoon season formed a cluster belonging to Zone B. Similarly, the sampling sites from BA13 to BA20 for post-monsoon season and BA11 to BA20 for pre-monsoon season were grouped under Zone C. The cluster analysis revealed that the moderately polluted river stretch extended $4 \mathrm{~km}$ upstream into Zone A during the pre-monsoon season, while at the same time, the 
Table 4. The major tributaries of Bagmati River with the environmental variables. (Abbreviations: Temp $=$ temperature $(\mathrm{C})$, Cond.$=$ conductivity $(\mu \mathrm{S} / \mathrm{cm}), D O=$ dissolved oxygen $(\mathrm{mg} / \mathrm{l}), B O D_{5}=$ biological oxygen demand $(\mathrm{mg} / \mathrm{l}), \mathrm{PO}_{4}-\mathrm{P}=$ ortho-phosphate phosphorus $(\mathrm{mg} / \mathrm{l}), \mathrm{NO}_{3}-\mathrm{N}=$ nitrate nitrogen $(\mathrm{mg} / \mathrm{l})$ ). Len denotes the total length of the tributary in kilometer.

\begin{tabular}{lrlrrrrrr}
\hline Tributaries & Len & Temp & $\mathrm{pH}$ & Cond & DO & $\mathrm{BOD}_{5}$ & $\mathrm{PO}_{4}-\mathrm{P}^{2}$ & $\mathrm{~N}^{-N O} \mathrm{~N}_{3}$ \\
\hline Nagmati & 7.9 & 18 & 7.2 & 26 & 7.32 & 1.54 & 0.05 & 0.05 \\
Manahara & 23.5 & 24.05 & 7.3 & 566 & 2.89 & 42.75 & 2.69 \\
Bishnumati & 17.3 & 25.71 & 7.3 & 1307 & 1.86 & 192.5 & 8.09 & 0.86 \\
Dhobi & 18.2 & 25.2 & 7.2 & 994 & 1.45 & 134 & 4.48 & 1.53 \\
Nakhu & 17.6 & 25.1 & 7.3 & 965 & 2.45 & 121.3 & 5.51 \\
Balkhu & 15.6 & 24.5 & 7.4 & 1614 & 1.33 & 123.8 & 9.61 \\
\hline
\end{tabular}

heavily polluted river stretch extended about $8 \mathrm{~km}$ into Zone B (figure 4c). Additionally, the CA results were supported by NMDS for both seasons (figure $5 \mathrm{a}$ and $\mathrm{b}$ ).

The sensitive invertebrate taxa of Ephemeroptera $(\mathrm{E})$, Plecoptera $(\mathrm{P})$ and Trichoptera $(\mathrm{T})$ were abundant in Zone A, while the moderately sensitive taxa of Diptera were abundant in Zone B, and the highly tolerant taxa of worms, leeches and red Chironomids were abundant in Zone C (figure 6). The taxa richness (S), Shannon Wiener diversity index (H), Evenness (e), Simpson's diversity index (D), total abundance, percent of EPT abundance (figure 7a) and the percent of worms and leeches abundance (figure $7 \mathrm{~b}$ ) varied significantly among the zones (Kruskal-Walis, $p>0.001, \mathrm{df}=2, N=20$, pre-monsoon).

\subsection{Identification of environmental variables}

Out of 15 environmental variables, only two variables for each season were independent and significant. Thus, only these variables were considered in the analysis. The three axes of the CCA indicated a $49.4 \%$ and a $48.1 \%$ cumulative variance in the species data for the post-monsoon and pre-monsoon seasons, respectively. The speciesenvironment correlations were 0.987 and 0.858 for the first and second axes in the post-monsoon season and 0.984 and 0.829 for the first and second axes in the pre-monsoon season. The eigenvalues for the three axes were $0.715,0.154$ and 0.174 for the post-monsoon season and $0.682,0.150$ and 0.295 for the pre-monsoon season.

The benthic assemblage at the urban section of the river was mainly affected by high orthophosphate phosphorus (post-monsoon) and chloride (pre-monsoon) (figure $8 \mathrm{a}$ and $\mathrm{b}$ ).

\subsection{Identification of stressors}

A total of 17 stressors identified during the river corridor survey and the relative importance of their occurrence frequency (121) are presented under four categories (table 5). The major stressors for urban river sections were industrial effluents, sewage, urban runoff, solid waste dumping along river banks, open defecation, and embankment and weir. In addition, the ritual activities along the river course at the temples such as cremation ashes, have added pollution to the river. Zone A had only a minimal level of disturbances caused by occasional human activities under category of Activities and Facilities. Zone B was affected by Activities and Facilities and Hydro-morphological Disturbances that accounted for $11.67 \%$ of the total stressors. Similarly, Activities and Facilities and Effluents accounted for $40 \%$ of the total stressors in Zone $\mathrm{C}$.

\section{Discussion}

Our analyses showed that the ecological status of the Bagmati River sharply decreased from rural areas to urban areas. The good ecological status of sampling sites in rural areas (BA01-BA07) was indicated by the high proportion of pollution sensitive benthic macroinvertebrates (Ephemeroptera, Plecoptera, Trichoptera, some Dipteran, etc.) which have higher GRSbios scores. The river reach habitats are intact, heterogeneous and are maintained with minimum water discharge, supporting higher taxa richness and diversity. The sites lie in the Shivapuri-Nagarjun National Park and are dominated by native deciduous forest. The deterioration of the river water quality begins as soon as it leaves the national park due to intense anthropogenic activities. The sites in the semi-urban areas (BA08-BA10) were primarily dominated by moderately pollution-tolerant benthic macroinvertebrates that led to lower GRSbios/ASPT values. Site BA08 is located just downstream of a small settlement where the first sewerage from individual households was recorded. Sites in urban areas (BA11-BA20) were colonized by a few highly pollution-tolerant benthic macroinvertebrates like 
(a)

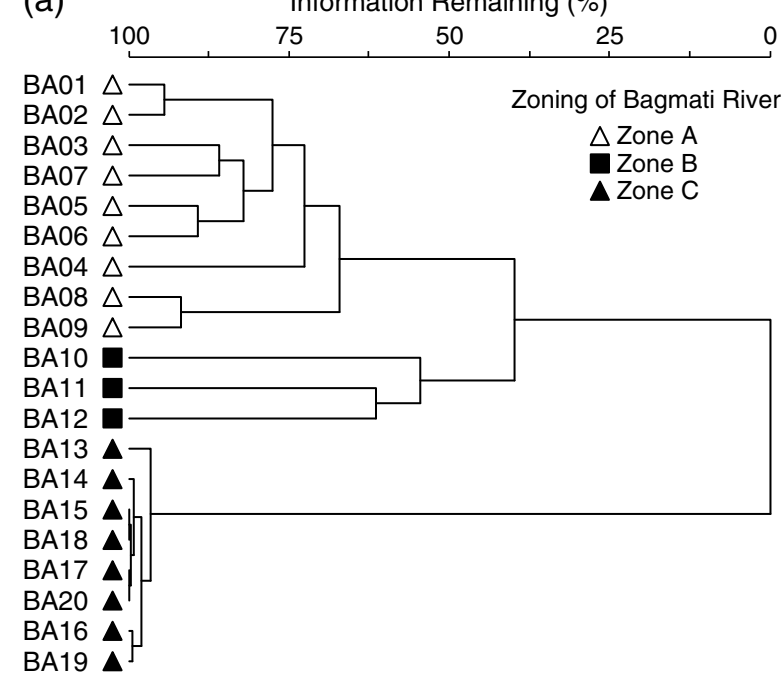

(b)
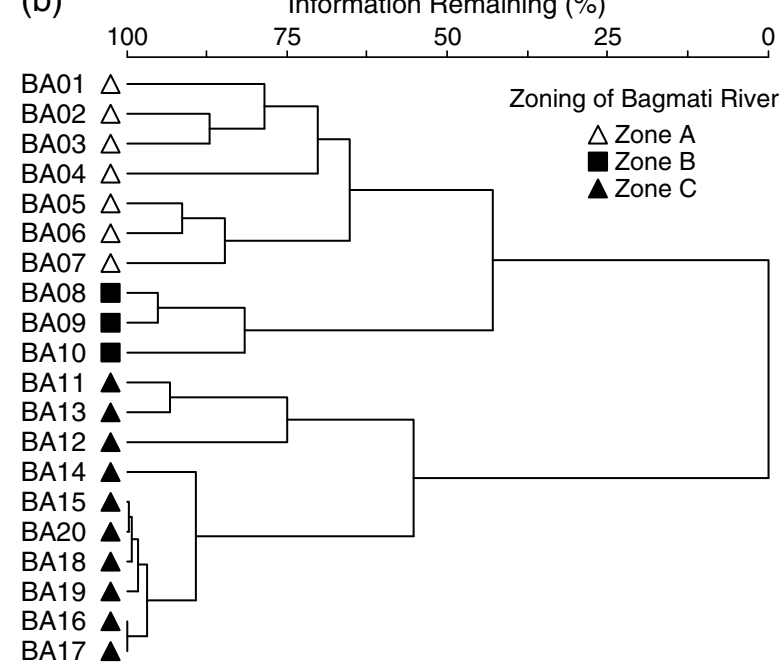

(c)

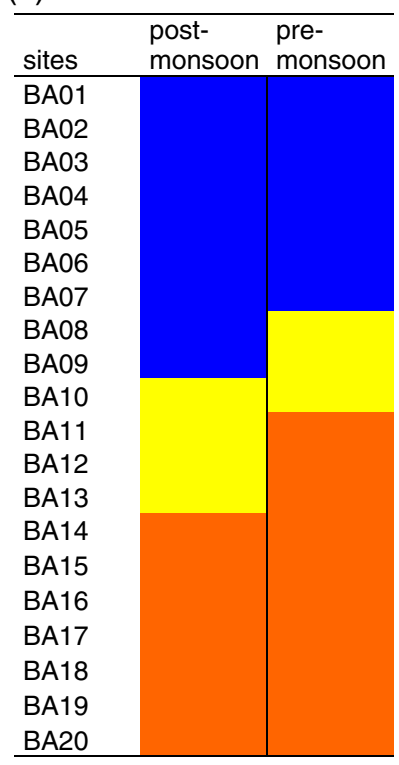

Figure 4. Cluster analysis based on abundance and composition of benthic macroinvertebrates. 'Zone A', 'Zone B' and 'Zone C' for (a) post-monsoon season and (b) pre-monsoon season. The shifting of zone is shown in (c).
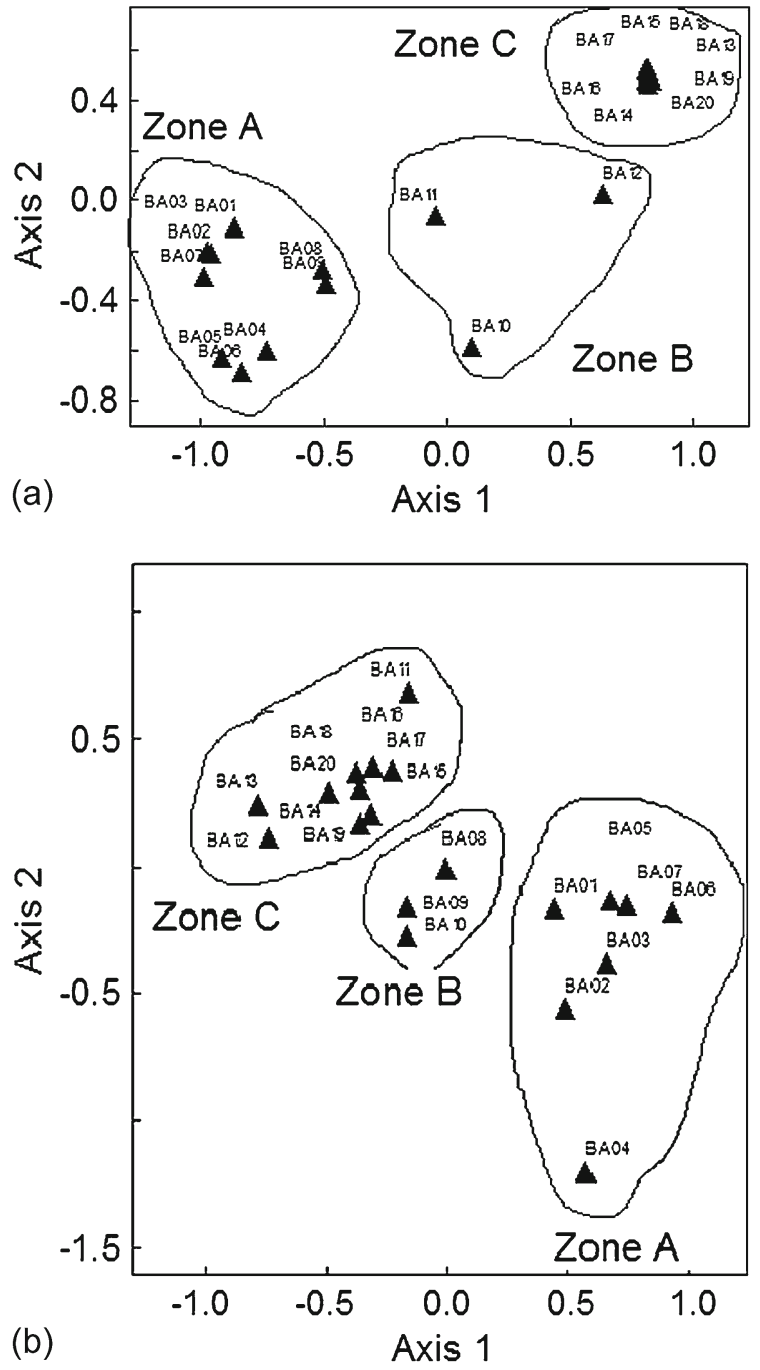

Figure 5. Non-metric multidimensional scaling (a) for postmonsoon season and (b) for pre-monsoon season provide three distinct zones: Zone A, Zone B and Zone C.

Tubificidae, red Chironomidae and white Psychodidae, which provide the lowest GRSbios/ASPT value and subsequently resulted in poor ecological status. The presence of only tolerant taxa in the urban river reach might have been favoured by the high portion of sludges (table 1). Our results are consistent with other studies conducted in the river (Shah et al. 2008; Shrestha et al. 2008a).

There are significant differences in the benthic macroinvertebrate assemblage among the three clusters representing the minimally, moderately and extremely polluted sections of the river, respectively. Zone A had minimal disturbances and is in reference status. Zone B was moderately deteriorated due to increasing human activities including extensive agricultural practices. In addition, effluents from both point and nonpoint pollution sources due to increasing population have led 


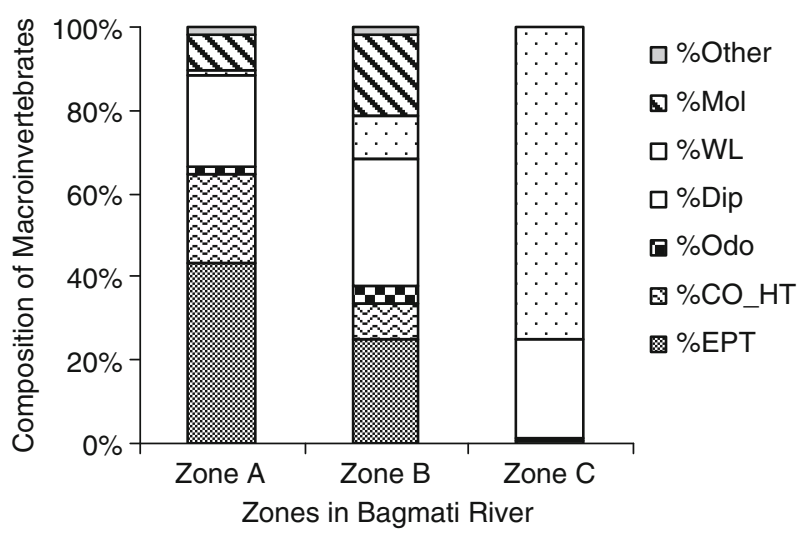

Figure 6. Composition of benthic macroinvertebrates in different zones based on relative abundance in the Bagmati River for pre-monsoon season. [Abbreviation: Other (Decapoda, Megaloptera and Tricladida), Mol - Mollusca, WL - Worms and Leeches, Dip - Diptera, Odo - Odonata, CO_HT - Coleoptera and Heteroptera and EPT Epheroptera, Plecoptera and Trichoptera (based on abundance).]
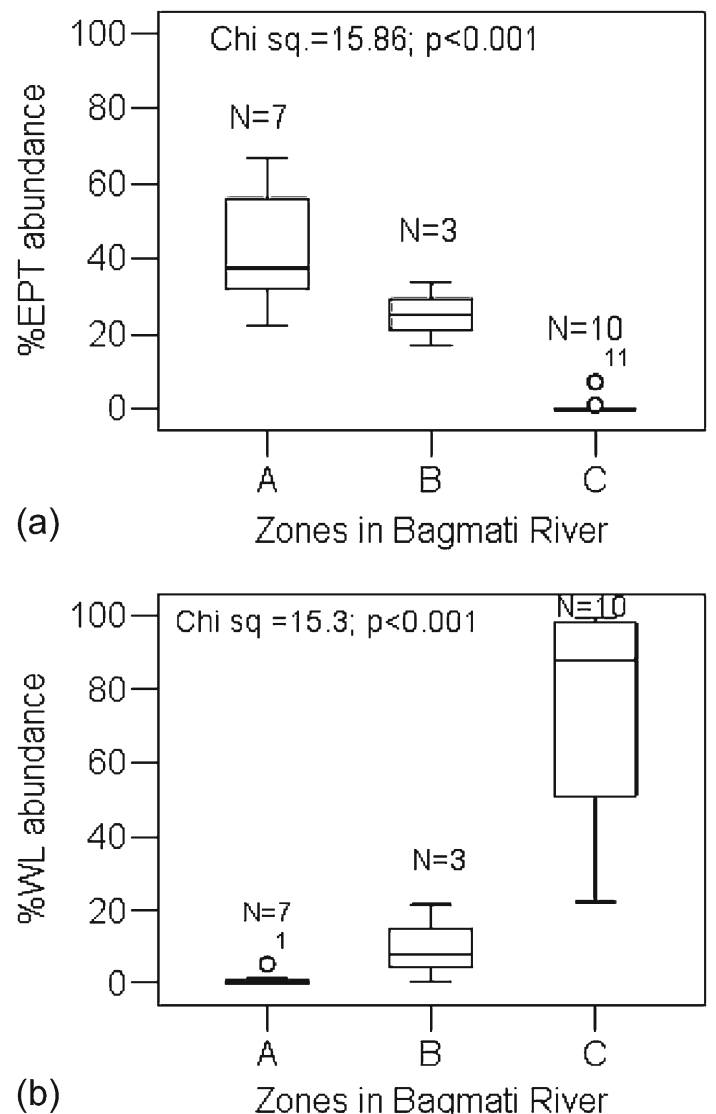

Figure 7. (a) Percentage of EPT abundance and (b) percentage of Worms and Leeches abundance among zones in Bagmati River for pre-monsoon season.

to a rapid deterioration in river water quality. Earlier studies classified this region as a less polluted region (mean DO $>6 \mathrm{mg} / \mathrm{l}$ ) during the study period 1999-2003 (Kannel et al. 2007c) and

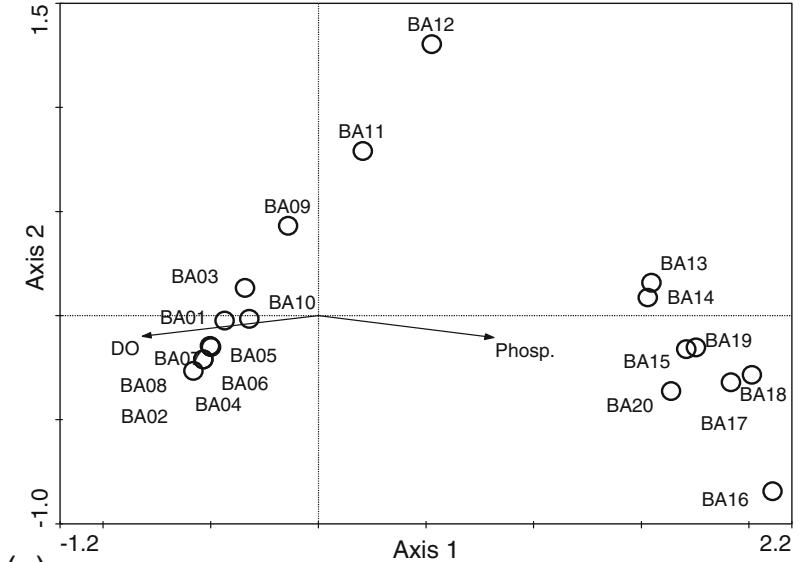

(a)

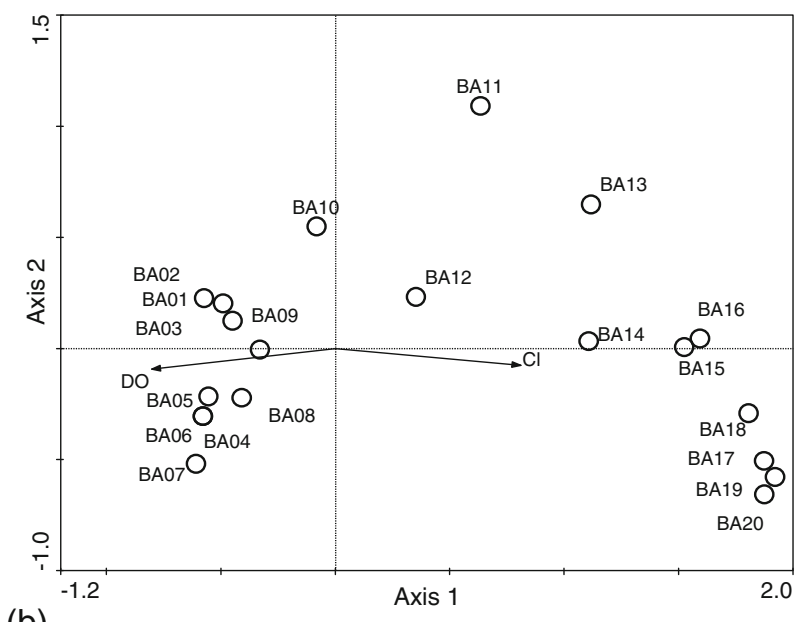

(b)

Figure 8. Ordination diagram of canonical correspondence analysis (CCA) biplot for benthic macroinvertebrates at 20 sampling sites in Bagmati River. Significant environmental variables are shown in vectors, (a) DO - Dissolved Oxygen (mg/l) and Ortho-phosphate phosphorus (mg/l) in CCA for post-monsoon and (b) DO - Dissolved Oxygen $(\mathrm{mg} / \mathrm{l})$ and $\mathrm{Cl}$ - Chloride $(\mathrm{mg} / \mathrm{l})$ in CCA for pre-monsoon season.

reported an increasing trend of nitrate pollution, indicating the increased use of fertilizers (Karn and Harada 2001). Zone C was extremely polluted as a consequence of cumulative stressors from the direct discharge of sewage and industrial effluents, the disposal of solid wastes along the banks and wastes from cultural and ritual activities (e.g. cremation ashes). Furthermore, the extremely polluted tributaries (table 4) drain into this segment. A wide range of untreated liquid and solid waste is discharged into these tributaries. For instance, the Bishnumati River receives raw sewage from municipal areas, untreated industrial effluents including the acids and toxic chemicals from carpet-making factories, hospital wastes, slaughter wastes including the disposal of blood, excreta, etc. The downstream section is used as an emptying spot for open sewers. These tributaries were 
classified as extremely polluted in other research findings as well (Pradhan 2005; Kannel et al. 2007c; Shrestha et al. 2008a).

The extension of the moderately polluted stretch upstream during the pre-monsoon season compared to the post-monsoon season (figure 4c) suggests that the degree of pollution in the river stretches varies seasonally. The moderately polluted sites in pre-monsoon transform into minimally polluted sites in the post-monsoon season as a consequence of increased water discharge. This indicates a self-purification capacity of the river segment (sensu Kannel et al. 2007b). During the pre-monsoon season, the water discharge in the river is comparatively lower than during the postmonsoon season, as the basin is strongly influenced by the monsoon. Further, tapping water for drinking purposes directly from the source of the river is one of the root causes of the decreasing downstream water discharge. The constant level of stress factors combined with a seasonally varying river discharge has exerted an enormous adverse impact on aquatic habitats since the water discharge decreases during the dry season, resulting in an increased pollution level.

The analytical results in our study indicate that $\mathrm{CA}$ is useful in offering reliable disturbance zonation of running waters and will make it possible to design a cost effective and more informative spatial sampling strategy (Kim et al. 2005) in running waters in the future. Many successful applications of CA to assess river water quality have been reported in last decade (Kannel et al. 2007a; Zhang et al. 2009). The three distinct groups in NMDS are in agreement with the results of CA, confirming the correct classification (sensu Kannel et al. 2007a).

Our results showed that EPT richness represented about $43 \%$ of the total faunal composition in Zone A, $25 \%$ in Zone B and less than $1 \%$ in Zone C (figure 6). These three orders (E, P, T) of benthic macroinvertebrates are considered important groups in the ecological assessment of surface water bodies because their richness, diversity and abundance decrease with increasing pollution gradients (e.g. Bournaud et al. 1996). In contrast, the percentage of the Worm and Leeches composition increased from $1 \%$ to $75 \%$ in Zone A to Zone C, respectively. Therefore, the significant differences in the percentages of EPT and WL abundance among the three zones are apparent and are similar to those from other ecological studies (e.g. Shah et al. 2011). The overall trend of reduced taxa richness and a shift from sensitive to tolerant taxa is an indication of multiple stressors (Norris and Georges 1993). The calculated diversity indices, which were typical of a stressed environment within the urbanized part of the catchment, support this (Norris and Georges 1993). The sensitivity to degradation often increases with higher taxonomic resolution but family-level data is more appropriate for detecting severe impacts (Bournaud et al. 1996; Taylor 1997; Jones 2008). Several studies have shown family-level data allow changes along an organically polluted river to be detected (e.g. Bournaud et al. 1996). Bournaud et al. (1996) found that the changes in family-level-based taxa richness and the Shannon diversity index along the river were similar to those observed when using the species level.

The water chemistry in rivers is regulated by a complex suite of processes that operate at various spatial and temporal scales (e.g. Johnson et al. 1997). The measured dissolved oxygen decreased from rural to urban areas while nitrate nitrogen, ortho-phosphate phosphorus, chloride and $\mathrm{BOD}_{5}$ greatly increased. The continuous discharge of sewage and industrial input (Kannel et al. 2007c) has led to increased levels of $\mathrm{BOD}_{5}$ and chloride. The higher level of dissolved oxygen in rural areas could be attributed to the water turbulence and fewer nutrients. However, the value is comparatively lower than that in the natural river system. This could be due to the low discharge in the river and the higher average water temperature of $11^{\circ} \mathrm{C}$ for the post-monsoon season and a temperature of above $19^{\circ} \mathrm{C}$ for the pre-monsoon season. The average water temperature was higher than previous records (see Pradhan 2005) for the sites. Dissolved oxygen, a barometer of the ecological health of the river, is the most important parameter for protecting aquatic life (Chang 2002). The US Environmental Protection Agency (US EPA 1986) has specified that the minimum DO (1-day minimum) necessary to support varied aquatic insect species is $4 \mathrm{mg} / \mathrm{l}$. The river stretches in the urban areas had a DO level below this standard, which has caused a great loss in aquatic diversity (figure 3). Further, the increased ortho-phosphate phosphorus concentration, which is higher than the standard limit $(0.1 \mathrm{mg} / \mathrm{l})$ in freshwater (US EPA 1986), has led to eutrophication, the depletion of the dissolved oxygen concentrations (Davie 2003), thereby altering the benthic macroinvertebrate assemblage downstream. The considerably high concentrations of chloride in urban areas during the pre-monsoon season clearly showed that a large volume of untreated sewage is discharged into the river.

The river water is degraded due to the direct discharge of untreated wastes and wastewater from domestic uses and industries (Haack and Rafter 2006). Further, industries producing vegetable oil, leather, carpet, dairy products, distilled products and beer have aggravated the situation (see Devkota and Neupane 1994). With increased 
Table 5. Stressors recorded during corridor survey (2008-2010). A total of 120 frequencies of stressors were recorded. The values are given in percent and calculated from frequency of occurrence of each stressor along river stretch of Bagmati River.

\begin{tabular}{|c|c|c|c|c|c|}
\hline Groups & Stressing factors & & Zone A & Zone B & Zone $\mathrm{C}$ \\
\hline \multirow[t]{5}{*}{ A. Effluents } & Agricultural effluent & & 0.83 & 2.5 & 2.5 \\
\hline & Industrial effluent & & & & 7.5 \\
\hline & Sewerage & & & 0.83 & 8.33 \\
\hline & Urban runoff & & & & 8.33 \\
\hline & & Sub total & 0.83 & 3.33 & 26.67 \\
\hline \multirow[t]{3}{*}{ B. Solid waste } & Waste dumping & & & 2.5 & 8.33 \\
\hline & Cremation site & & & & 5.83 \\
\hline & & Sub total & & 2.5 & 14.17 \\
\hline \multirow[t]{7}{*}{ C. Activities and facilities } & Littering by picnic goers & & 2.5 & 0.83 & 1.67 \\
\hline & Bathing and washing & & 0.83 & 2.5 & 2.5 \\
\hline & Squatter settlements & & & & 3.33 \\
\hline & Open defecation & & & 2.5 & 8.33 \\
\hline & Vehicle crossing along river & & & 0.83 & \\
\hline & Temples & & 1.67 & 0.83 & 5 \\
\hline & & Sub total & 5 & 7.5 & 20.83 \\
\hline \multirow{6}{*}{$\begin{array}{l}\text { D. Hydro-morphological } \\
\text { disturbances }\end{array}$} & Bank cutting, & & & 0.83 & 5 \\
\hline & Embankment and weir & & & & 6.67 \\
\hline & Water for irrigation & & & 2.5 & \\
\hline & Reservoir and impoundment & & 0.83 & & 1.67 \\
\hline & Stone quarrying and Sand quarrying & & & 0.833 & 0.833 \\
\hline & & Sub total & 0.83 & 4.17 & 14.17 \\
\hline
\end{tabular}

pollution, the river has lost its assimilative capacity (Bottino et al. 1990) and has become an open sewer at the downstream section. Various studies (Pradhan 2005; Shrestha et al. 2008a) have concluded that water pollution in the urban areas is mainly related to the municipal sewage system. This has been further supported in our study by the identification of ortho-phosphate phosphorus and chloride as major influencing factors in downstream. Sewage, municipal waste and fertilizers have contributed to the higher concentration of phosphorus as has the domestic use of laundry detergents (Alvarez Cobelas et al. 1992; Karafistan et al. 2002; Kannel et al. 2007c). The use of phosphorus detergents for household laundry was banned in the developing countries in the 1980s/1990s, but it has not yet been banned in Nepal (Kannel et al. 2007c).

The corridor survey conducted in this study provided an approximation of the major stress factors that deteriorate the ecological status of the Bagmati River. The increasing number of stressors in the downstream section of the river not only threatens the riverine ecosystem and aquatic biodiversity but also reduces the river's selfpurification capacity (e.g. Bottino et al. 1990; Shrestha et al. 2008a). Stressors related to the Activities and Facilities category represented a high proportion of the stressors in each zone of the river, suggesting the river is severely affected by various kinds of human influences.
Nevertheless, the Effluents, Solid waste deposition and Hydro-morphological disturbances categories have altered reach habitat composition, physico-chemical properties and subsequently, faunal composition, hence changing the ecological status.

The population growth in the Kathmandu Valley is the key factor governing the river pollution. The Bagmati River degradation has been positively correlated with population density $(r=0.83)$ and built up area $(r=0.95)$ (values based on NTNC 2009). The urban growth rate in Nepal (6.6\% per annum) is among the highest in the Asian and Pacific region (ADB/ICIMOD 2006), higher than that in Sri Lanka (2.2\%), India (2.9\%), Pakistan (4.4\%), Bangladesh (5.3\%) and Cambodia (6.2\%). The economic opportunities in the urban areas, population growth in the semi-urban areas and the political situation in the rural areas are the major factors driving the urban growth in the Kathmandu Valley (Thapa and Murayama 2010).

Benthic macroinvertebrates, as biological indicators of stream water quality, can be utilized to identify impaired river stretches, determine aquatic life stressors, set goals for reducing impairment, and indicate improvement (Kenny et al. 2009). Physico-chemical parameters, which provide snapshots of the condition of a waterbody, do not provide the integrative measure of overall health of a stream and can, at times, inadequately identify impaired waters (United States Environmental 
Protection Agency (US EPA) 2005). Instead, biological measures provide an integrated, comprehensive assessment of the health of a waterbody overtime (Karr 1999). Benthic macroinvertebrates are robust indicators that summarize a range of environmental responses and are usually understood by resource managers and the public. In addition, benthic macroinvertebrates are good indicators of the effectiveness of restoration as they respond rapidly to restoration activities (Stanley et al. 2002; Maloney et al. 2008). This indicatorbased river quality assessment and classification could be an effective management tool in the region.

The river water quality in South Asian (Hindu Kush Himalayan) countries is poor (Shrestha et al. 2008b) and is deteriorated by the direct discharge of industrial, municipal, agricultural and solid wastes. A poor ecological status and the loss or alteration of aquatic diversity is common, particularly when the rivers pass through the urban areas of the region. The restoration and proper management of these degraded riverine ecosystems is essential for continuously providing ecosystem services including clear water, fresh air, recreational activities, mitigation of drought and floods, the cycling and transport of nutrients, the maintenance of biodiversity, detoxification, decomposition of waste, and so forth.

Water managers should take precaution while choosing restoration approaches, because one approach designed for a particular stressor or catchment may not function well for a river facing a broad range of degradations. Legal mandates (e.g. WFD in the European Union, Clean Water Act in United States) for river management could help to regulate the region's river ecosystems. For any restoration processes, an attainable goal for the river or watershed has to be considered. A success in river restoration largely depends on determining the answers to management questions such as how much river restoration the nation needs; how the nation can best achieve cost-effective river restoration; and which criteria are needed to know whether there is enough restoration in the area (see Beechie et al. 2009).

\section{Conclusion}

Our benthic macroinvertebrate assemblage analysis reflected the actual ecological status of the studied sites; the status ranged from reference to extremely polluted. The cluster analysis grouped the sampling sites into three disturbance zones: Zone A, Zone B and Zone C. Since the Bagmati River is a seasonal river, Zones $\mathrm{B}$ and $\mathrm{C}$ shift upstream during the pre-monsoon season, when less rainfall results in less river discharge compared to the increased discharge of the post-monsoon season. Because of this, the pre-monsoon season might be the best season to assess the ecological statuses and capture the overall ecological condition, where the basin is influenced by seasonal phenomena.

We found that the ortho-phosphate phosphorus and chloride were the major influencing environmental variables impacting the benthic assemblage in the downstream section of the Bagmati River. The main stressors causing the river pollution were Effluents, Activities and Facilities, Solid Wastes and Hydro-morphological disturbances.

We believe the determination of the various disturbance zones and their associated stress factors should help water managers and planners to correctly prioritize which measures best address the problems of water degradation and the accompanying loss of biodiversity in urban rivers. Our results show that multivariate analysis can be used to understand the complex nature of water quality issues and determine priorities in improving water quality. This method could serve to optimize cost and time without any significant change in the outcome compared to other methods.

\section{References}

ADB/ICIMOD 2006 Environment assessment of Nepal: Emerging issues and challenges; Kathmandu, ICIMOD, $239 \mathrm{p}$.

Alvarez Cobelas M A, Rubio-Olmo A and Muñoz Ruiz P 1992 Eutrophication in Spanish freshwater ecosystems; Limnetica 8 263-266.

APHA 1995 Standard methods for the examination of water and wastewater; APHA, Washington DC, 19th edn.

Barbour M T 2008 The societal benefit of biological assessment and monitoring in rivers; In: Proceeding of the Scientific Conference Rivers in the Hindu Kush-HimalayanEcology and Environment Assessment (eds) Moog O, Hering D, Sharma S, Stubauer I and Korte T, pp. 5-7.

Beechie T J, Pess G R, Pollock M N, Ruckelshaus M H and Roni P 2009 Restoring rivers in the twenty-first century: Science challenges in a management context; Fish \& Fisheries Series 31 697-717.

Bhardwaj V, Singh D S and Singh A K 2010 Water quality of the Chhoti Gandak River using principal component analysis, Ganga Plain, India; J. Earth Syst. Sci. 119 $117-127$.

Bonada N, Prat N, Resh V H and Statzner B 2006 Developments in aquatic insect biomonitoring: Comparative analysis of recent approaches; Ann. Rev. Entomol. 51 495-523.

Bottino A, Bruno F, Trinetra M P, Augusto S, Sharma S and Thapa A 1990 Pollution monitoring of the Bagmati River; J. Nepal Chem. Soc. 9 26-45.

Bournaud M, Cellot B, Richoux P and Berraho A 1996 Macroinvertebrate community structure and environmental characteristics along a large river: Congruity of patterns for identification to species or family; J. N. Am. Benthol. Soc. 15 232-253. 
Campbell I C 1978 A biological investigation of an organically polluted urban stream in Victoria; Aust. J. Mar. Freshwater Res. 29 275-291.

Central Bureau of Statistics 2002 Statistical pocket bookNepal; His Majesty's Government, National Planning Commission Secretariat Publ.; Kathmandu, Nepal.

Chang H 2002 Spatial and temporal variations of water quality in the river and its tributaries, Seoul, Korea, 1993- 2002; Water Air Soil Pollut. 161 267-284.

Commonwealth Environment Protection Agency (Australia) 1992 Towards healthier rivers: The ills affecting our rivers and how we might remedy them; CEPA, Canberra.

Davie T 2003 Fundamentals of hydrology; New York, Routledge, 169p.

Devkota S R and Neupane C P 1994 Industrial pollution inventory of the Kathmandu Valley and Nepal; Kathmandu Industrial Pollution Control Management Project, HMG/MOI/UNIDO/91029.

Downes B J, Barmuta L A, Fairweather D P, Keough M J, Lake P S, Mapstone B D and Quinn G P 2002 Monitoring Ecological Impacts. Concepts and practice in flowing waters (Cambridge, England: Cambridge University Press), 434p.

Dudgeon D 1999 Tropical Asian Stream: Zoobenthos, Ecology and Conversation; Hong Kong University Press, $830 \mathrm{p}$.

European Commission, Directive 2000/60/EC of the European Parliament 2000 Establishing a framework for Community action in the field of water policy; Official Journal of the European Communities L327 1-72.

Fulazzaky M A, Seong T W and Masirin M M 2010 Assessment of water quality status for the Selangor River in Malaysia; Water Air Soil Pollut. 205 63-77.

Ghimire G P 1985 Water pollution - A major crisis in Nepal; Environmentalist 5(3) 193-195.

Ha S R and Pokhrel D 2001 Water quality management planning zone development by introducing a GIS tool in Kathmandu valley, Nepal; Water Sci. Technol. 44(7) 209-221.

Haack B N and Rafter A 2006 Urban growth analysis and modeling in the Kathmandu valley, Nepal; Habitat Int. 30 1056-1065.

Johnson L U, Richards C, Host E G and Arthur J W 1997 Landscape influences on water chemistry in Midwestern stream ecosystems; Freshwater Biol. 37 193-208.

Jones F C 2008 Taxonomic sufficiency: The influence of taxonomic resolution on freshwater bioassessments using benthic macroinvertebrates; Environ. Rev. 16 45-69.

Kannel P R, Lee S, Kanel S R, Khan S P and Lee Y S 2007a Spatial-temporal variation and comparative assessment of water qualities of urban river system: A case study of the river Bagmati (Nepal); Environ. Monit. Assess. 129 433-459.

Kannel P R, Lee S, Kanel S R and Khan S P 2007b Chemometric application in classification and assessment of monitoring locations of an urban river system; Anal. Chim. Acta 582(2) 390-399.

Kannel P, Lee S, Lee Y S, Kanel S and Khan S 2007c Application of water quality indices and dissolved oxygen as indicators for river water classification and urban impact assessment; Environ. Monit. Assess. 132 93-110.

Karafistan A, Martin J M, Rixen M and Beckers J M 2002 Space and time distributions of phosphate in the Mediterranean Sea; Deep-Sea Res. 49 67-82.

Karn S K and Harada H 2001 Surface water pollution in three urban territories of Nepal, India, and Bangladesh; Environ. Manag. 28 483-496.

Karr J R 1999 Defining and measuring river health; Freshwater Biol. 41 221-234.
Kenny M A, Sutton-Grier A E, Smith R F and Gresens S E 2009 Benthic macroinvertebrates as indicators of water quality: The intersection of science and policy; Terr. Arthropod Rev. 2 99-128.

Kim J H, Kim R H, Lee J, Cheong T J, Yum B W and Chang H W 2005 Multivariate statistical analysis to identify the major factors governing groundwater quality in the coastal area of Kimje, South Korea; Hydrol. Process. 19 1261-1276.

Leung A S, Li A O Y and Dudgeon D 2012 Scales of spatiotemporal variation in macroinvertebrate assemblage structure in monsoonal streams: The importance of season; Freshwater Biol. 57 218-231.

Maloney K O, Dodd H R, Butler S E and Wahl D H 2008 Changes in macroinvertebrate and fish assemblages in a medium-sized river following a breach of a low-head dam; Freshwater Biol. 53 1055-1068.

Marchant R, Wells F and Newall P 2000 Assessment of an Ecoregion approach for classifying macroinvertebrate assemblages from streams in Victoria, Australia; J. Am. Benthol. Soc. 19 497-500.

McCune B A and Mefford M J 2006 Multivariate Analysis of Ecological Data; Version 5.16; MjM Software, Gleneden Beach, Oregon, USA, PC-ORD.

Moog O 2007 Manual on pro-rata multi-habitat-sampling of benthic invertebrates from wadeable rivers in the HKHregion; Deliverable 8, Part 1 for ASSESS-HKH, European Commission, 29p, http://www.assess-hkh.at.

Nesemann H, Sharma S, Sharma G, Khanal S N, Pradhan B, Shah D N and Tachamo R D 2007 Aquatic Invertebrates of the Ganga River System (Mollusca, Annelida, Crustacea), vol. 1, Kathmandu.

Nesemann H, Shah R D T and Shah D N 2011 Key to the larval stages of common Odonata of Hindu Kush Himalaya, with short notes on habitats and ecology; J. Threatened Taxa 3 2045-2060.

Norris R H and Georges A 1993 Analysis and interpretation of benthic macroinvertebrate surveys; In: Freshwater Biomonitoring and Benthic Macroinvertebrates (eds) Rosenberg D M and Resh V H (New York: Chapman \& Hall), pp. 234-286.

NTNC (National Trust for Nature Conservation) 2009 Bagmati Action Plan (2009/10-2014/15); Kathmandu, Nepal, 67p.

Pradhan B 2005 Water quality classification model in the Hindu Kush-Himalayan region: The Bagmati River in Kathmandu Valley, Nepal; http://geoportal.icimod.org.

Raj N and Azeez P A 2009 Spatial and temporal variation in surface water chemistry of a tropical river, the river Bharathapuzha, India; Curr. Sci. 96 245-251.

Resh V H 2008 Which group is best? Attributes of different biological assemblages used in freshwater biomonitoring programs; Environ. Monit. Assess. 138 131-138.

Robinson C T, Aebischer S and Uehlinger U 2004 Immediate and habitat-specific responses of macroinvertebrates to sequential, experimental floods; J. N. Am. Benthol. Soc. 23 853-867.

Rosenberg D M and Resh V H 1993 Introduction to freshwater biomonitoring and benthic macroinvertebrates; In: Freshwater biomonitoring and benthic macroinvertebrates (eds) Rosenberg D M and Resh V H (New York: Chapman and Hall), pp. 1-9.

Shah R D T and Shah D N 2012 Performance of different biotic indices assessing the ecological status of rivers in the central Himalaya; Ecol. Indic. 23 447-452.

Shah D N, Tachamo R D, Sharma S and Moog O 2008 Cause and implications of urban river pollution, mitigative measures and benthic macroinvertebrates as river monitoring tool; In: Proceedings of International Conference 
on Water and Urban Development Paradigms: Towards an Integration of Engineering, Design and Management Approaches (eds) Feyen J, Shannon K and Neville M, pp. 419-424.

Shah R D T, Shah D N and Nesemann H 2011 Development of a macroinvertebrate-based Nepal Lake Biotic Index (NLBI): An applied method for assessing the ecological quality of lakes and reservoirs in Nepal; Int. J. Hydrol. Sci. Technol. 1(1/2) 125-146.

Shrestha M, Pradhan B, Shah D N, Tachamo R D, Sharma $\mathrm{S}$ and Moog O 2008a Water quality mapping of the Bagmati river basin, Kathmandu valley; In: Proceedings of Scientific Conference on Rivers in the Hindu Kush Himalaya: Ecology and Environmental Assessment (eds) Moog O, Hering D, Sharma S, Stubauer I and Korte T, pp. 189-198.

Shrestha M, Pradhan B, Hoffmann A, Chhopel G K, Bari M F, Khalown M A, Sharma M P and Sharma S 2008b River's water quality pressure, impacts and policies in the Hindu Kush-Himalaya; In: Proceedings of Scientific Conference on Rivers in the Hindu Kush Himalaya: Ecol. Environ. Assess. (eds) Moog O, Hering D, Sharma S, Stubauer I and Korte T, pp. 137-143.

Shrestha M, Pradhan B, Tachamo R D, Shah D N, Sharma S and Moog O 2009 Water quality assessment and associated stressing factors of the Seti River Basin, Pokhara Sub Metropolitan City; J. Hydrol. Meteorol. 6 49-57.

Stanley E H, Luebke M A, Doyle M W and Marshall D W 2002 Short-term changes in channel form and macroinvetebrate communities following low-head dam removal; J. N. Am. Benthol. Soc. 21 172-187.

Stubauer I, Hering D, Korte T, Hoffmann A, Brabec K, Sharma S, Shrestha M, Kahlown M, Tahir M, Kumar A, Sharma M, Bari M, Badruzzaman A, Chhopel G and Moog O 2010 The development of an assessment system to evaluate the ecological status of rivers in the Hindu Kush-Himalayan region: Introduction to the special feature; Hydrobiologia 65 11-15.

Taylor B R 1997 Rapid assessment procedures: Radical reinvention or just sloppy science?; Hum. Ecol. Risk Assess. 3 1005-1016.

Ter Braak C J F and Smilauer P 2002 CANOCO reference manual and user's guide to Canoco for Windows: Software for Canonical Community Ordination (version 4.5); Microcomputer Power, Ithaca, NY, US.

Thapa R B and Murayama Y 2010 Drivers of urban growth in the Kathmandu valley, Nepal: Examining the efficacy of the analytic hierarchy process; Appl. Geog. 30 70-83.

US EPA (United States Environmental Protection Agency) 1986 Gold Book quality criteria for water; Washington, District of Columbia: Office of Water Regulations and Standards, EPA 440/5-86-001.

US EPA (United States Environmental Protection Agency) 2005 Water Quality Standards Academy: Basic Course; Office of Water, Washington District of Columbia, USA, $152 \mathrm{p}$.

Williams A E 1998 Natural and anthropogenic nitrate contamination of groundwater in a rural community, California; Environ. Sci. Technol. 32 32-39.

Zhang Q, Li Z, Zeng G, Li J, Fang Y, Yuan Q, Wang Y and Ye F 2009 Assessment of surface water quality using multivariate statistical techniques in red soil hilly region: A case study of Xiangjiang watershed, China; Environ. Monit. Assess. 152 123-131.

Zhou F, Liu Y and Guo H 2007 Application of multivariate statistical methods to water quality assessment of the watercourses in northwestern new territories, Hong Kong; Environ. Monit. Assess. 132 1-13. 